\title{
Synthesis and Study of Modified Polyvinyl Alcohol Containing Amino Acid Moieties as Anticancer Agent
}

\author{
ALI H. SAMIR, RUWAIDAH S. SAEED* and FADHEL S. MATTY \\ Department of Chemistry, College of Education for Pure Science (Ibn Al-Haitham) / University of \\ Baghdad, Iraq. \\ ${ }^{*}$ Corresponding author E-mail: dr.mohammd08@gmail.com
}

http://dx.doi.org/10.13005/ojc/340131

(Received: July 23, 2017; Accepted: November 03, 2017)

\begin{abstract}
A series of new phthalimides compounds[ $3-7]_{\mathrm{a}-\mathrm{i}}$ were synthesized from reaction of Malic anhydride, phthalic anhydride, nitro phthalic anhydride, 2-phenyl-4H-benzo[d][1,3]oxazin-4-one, 2-(4-nitrophenyl)-4H-benzo[d][1,3]oxazin-4-one with different amino acids as glycine, alanine, valine, leucine, isoleucine, serine, threonine, tyrosine and Phenyl alanine $[1]_{\mathrm{a}-\mathrm{i}}$ under fusion conditions. Compounds [3-7 $]_{\mathrm{a}-\mathrm{i}}$ react with $\mathrm{SOCl}_{2}$ in the presence of benzene to produce compounds [8-12 $]_{\mathrm{a}-\mathrm{i}}$. Chemical modification of Poly(vinyl alcohol)were obtained by reaction of PVA with compounds [8$12]_{\mathrm{a}-\mathrm{i}}$ using the dimethyl formamide to give compounds [13-17 $]_{\mathrm{a}-\mathrm{i}}$. The structure of the synthesized compounds was characterized by their analytical and spectral data as, IR spectra, ${ }^{1} \mathrm{H},{ }^{13} \mathrm{C}-\mathrm{NMR}$, Elemental analysis (CHN), UV-Vis Spectroscopy, Scanning electron microscopy (SEM), Antibacterial activity were screened via two kinds of bacteria. Also, anticancer activity were examined for most of the modified polyvinyl alcohol.
\end{abstract}

Keywords: Phthalimide, Polyvinyl alcohol, antibacterial and anticancer activities.

\section{INTRODUCTION}

Cyclic imides and their derivatives brought much attention to chemist and pharmacist in the field of research and development ${ }^{1}$, These compounds play an important role in medicinal chemistry in drug development and drug discovery ${ }^{2}$. They Researches used these compounds as antibacterial ${ }^{3}$, analgesic ${ }^{4}$, nerve conduction blocking ${ }^{5}$, hypotensive ${ }^{6}$, muscle relaxant $^{7}$, antitumor ${ }^{8}$ antitubercular agents ${ }^{9}$ and antinociceptive agents, Also, these compounds interest as reactants for polymer synthesis ${ }^{10}$.

In addition compounds containing phthalimide moiety are distinguished with antimicrobial ${ }^{11-13}$, anti-inflammatory, anxiolytic, antiviral, antibacterial and antitumor properties ${ }^{14,15}$ 
Polyvinyl alcohol (PVA)is a water-soluble polyhydroxy polymer, non-halogenated aliphatic polymers, that has a two dimensional hydrogen-bonded network sheet structure ${ }^{16}$.

PVA is a semi-crystalline polymer containing crystalline and amorphous phase ${ }^{17}$ which is used in biomedical and pharmaceutical applications ${ }^{18}$ and in industries due to the excellent chemical and physical properties, non-toxicity, good chemical resistance, good film formation capacity. ${ }^{19}$

It has been applied in production of many end products, as lacquers, resins, surgical threads, and food packaging materials ${ }^{20}$.

Encouraged by these observation, the present study to synthesize new series of imide compounds containing amino acids with different heterocycles they may be have more activity and less toxicity as anticancer agents.

Aim of the present work is directed toward modification of polyvinyl alcohol containing active moiety with screened of antibacterial and anticancer activities.

\section{EXPERIMENTAL}

\section{A-Materials}

All the chemical used in the synthesis were supplied from $\mathrm{BDH}$ and Sigma-Aldrich.

\section{B - Instrumentation}

Melting points were recorded using electro thermal melting point apparatus and are uncorrected.

Infrared spectra were recorded as $\mathrm{KBr}$ disc on SHIMADZU-FT-IR-8400 spectrometer. ${ }^{1} \mathrm{H}$, ${ }^{13} \mathrm{C}-\mathrm{NMR}$ spectra was recorded on Bruker $500 \mathrm{MHz}$ instrument using DMSO- $\mathrm{d}_{6}$ as a solvent and TMS as internal reference, measurement were made at Central lab, Tahran University (Iran). the progress of the reaction was monitored by TLC using aluminum silica gel plates .

\section{Synthesis of compounds [2] $]_{\mathrm{a}, \mathrm{b}}{ }^{21}$.}

Benzoyl chloride or 4-nitrobenzoyl chloride (0.02 mole) was added to a solution of 2-aminobenzoic acid (0.01 mole) in $(30 \mathrm{ml}$.) pyridine. The mixture was shaken for $5 \mathrm{~min}$. and then kept in room temperature with shaking for $25 \mathrm{~min}$. Mixture was reacted with $15 \mathrm{ml}$. 10\% $\mathrm{NaHCO}_{3}$, filtered, washed with water, dried and the crude product was recrystalized from absolute ethanol. The yield of compound[2] was $81 \%$, m.p. (126) and [2] was $77 \%$, m.p (144).

\section{General procedure for Preparation of compounds $[3-7]_{\mathrm{a}-\mathrm{i}}^{22}$.}

A mixture of equimolar amounts $(0.001$ mole) of commercially available malic anhydride, phthalic anhydride, nitro phthalic anhydride, 2-phenyl-4H-benzo[d][1,3]oxazin-4-one, 2-(4-nitrophenyl)-4H-benzo[d] [1,3] oxazin-4-one were treated with corresponding amino acids[ 1$]_{a}$ in glacial acetic acid (15 ml.).

Mixture was refluxed for ( $5 \mathrm{~h}$ ). A liquot of $25 \mathrm{ml}$. of ice distilled water was added to the reaction. The compounds was filtered, dried and recrystallized from ethanol. The nomenclature and physical properties for prepared compounds

[3-7 $]_{\mathrm{a}-\mathrm{i}}$. were shown in Table. (1) Elemental analysis of compound[3]

Calcd: $C \%=54.82 \quad \mathrm{H} \%=5.58 \quad \mathrm{~N} \%=7.10$

Found: $\mathrm{C} \%=54.69 \quad \mathrm{H} \%=5.42 \quad \mathrm{~N} \%=6.21$

Elemental analysis of compound[5]

$\begin{array}{lll}\text { Calcd: } C \%=60 & \mathrm{H} \%=3.52 & \mathrm{~N} \%=8.23 \\ \text { Found: } \mathrm{C} \%=58.7 & \mathrm{H} \%=4.62 & \mathrm{~N} \%=7.71\end{array}$

\section{Synthesis of compounds [8-12 $]_{\mathrm{a}-\mathrm{i}}{ }^{23}$}

A mixture of compound $[3-7]_{\mathrm{a}-\mathrm{i}}$ (0.01mole) and thionyl chloride $(0.01 \mathrm{~mole})$ placed in dry benzene $(10 \mathrm{ml}$.) and refluxed for 7 hours. The excess of thionyl chloride and benzene were removed under vacuum after cooling .

\section{Synthesis of polymers [13-17] ${ }_{\mathrm{a}-\mathrm{i}}{ }^{24}$}

(1mole) of PVA and (1mole) of compounds [8-12 $]_{\mathrm{a}-\mathrm{i}}$ were placed in $20 \mathrm{ml}$ DMF. The mixture was frequent shaking for $3 \mathrm{hr}$. then refluxed for $2 \mathrm{~h}$ product was poured into the water, washed with a little sodium bicarbonate, washed with water, then with ethanol. The product purified by DMSO and reprecipitating from ethanol. 


\section{Biological Activity \\ Antibacterial activity}

Some of synthesized compounds have been screend for antibacterial activities against (Bacillus cereus and Esherichia coli) using cup-plate agar diffusion method ${ }^{25}$. The zone of inhibition measured in $\mathrm{mm}$. Pencilin was $(50 \mu \mathrm{g} / \mathrm{ml})$ were used as a standard drug for antibacterial activity to compare with the activity of the synthesized compounds.

\section{Cytotoxicity Assay}

Preparation of Cell Lines for Cytotoxicity Assay ${ }^{26}$

Fifteen modified PVA compound with different sizes and concentrations were screened for their anticancer activity and cytotoxicity by using cultured cells in microtiter plate (96 wells). The assay was applied by the following steps:

A-Seeding: When cells in the incubated falcon became monolayer, the confluent monolayer was trypsinzed to get single cell suspension. A liquot $200 \mu \mathrm{l} / 10^{4}-10^{5}$ cells/well from single cell suspension then were added to all the 96 wells of the microtiter plates, which covered by plate lids and sealed with adhesive parafilm. The plate was shaked gently and returned to the incubator.

B-Incubation: Microtiter Plates were then incubated in humidified chamber at $37{ }^{\circ} \mathrm{C}, 5 \% \mathrm{CO}_{2}$ until the cells reached confluence (i.e., vary according to the type of cell line). The plate was checked out for contamination, after cells attachment

C- Exposure: When the cells are in full of its activity, they were expose.d to three concentrations of the fifteen modified of PVA $\mu \mathrm{g} / \mathrm{ml}$ for cell line. Aliquot of $200 \mu \mathrm{l}$ of each concentration were pipette into each well, while $200 \mu \mathrm{l}$ of maintenance medium were added to each well of control group, then plates were sealed with adhesive parrafilm and returned to the incubator. Evaluation of cytotoxicity was carried out after 48 hours. The photo picture were taken after 24 hours.

D- Staining: Cell viability was measured after $48 \mathrm{~h}$ of exposure by removing the medium, adding $20 \mu \mathrm{l} /$ well solution of MTT and incubating for $4 \mathrm{~h}$ at $37^{\circ} \mathrm{C}$. The crystals remaining in the wells were solubilized by the addition of $200 \mu \mathrm{l} /$ well of
(DMSO) followed by incubation in $37^{\circ} \mathrm{C}$ for $15 \mathrm{~min}$. with shaking. The absorbance was measured on a microplate reader at $620 \mathrm{~nm}$. The rate of inhibition of cell growth was calculated according to ${ }^{27}$ follow equation.

Inhibition rate $=$ mean of control-mean of treatment $x 100(1.1)$

mean of control

\section{RESULTS AND DISCUSSION}

Scheme (1) summarized the performed reactions in this work. The structure of compounds $[2]_{\mathrm{a}, \mathrm{b}}$ were confirmed from its correct analytical and spectral data . FT-IR spectrum of compound [2] $]_{b}$, Fig. (3.1), showed ${ }^{21}$ appearance band at (1766) $\mathrm{cm}^{-1}$ due to the carbonyl group of cyclic ester, (1666, 1614) $\mathrm{cm}^{-1}$ due to the $\mathrm{C}=\mathrm{N}$ group and $(1585) \mathrm{cm}^{-1}$ due to the $\mathrm{C}=\mathrm{C}$ group. The ${ }^{1} \mathrm{H}-\mathrm{NMR}$ spectrum of compound [2 $]_{b}$, Fig. (3.2) display the following characteristic chemical shifts, (DMSO) ppm : the aromatic ring protons of compound [2] appeared as multiple at $\delta(6.41-8.64) \mathrm{ppm}$.

$N$-phthaloyl amino acid derivative $[3-7]_{\mathrm{a}-\mathrm{i}}$ using economical experimental conditions via reaction Malic anhydride, phthalic anhydride, nitro phthalic anhydride, 2-phenyl-4H-benzo[d] [1,3] oxazin-4-one, 2-(4-nitrophenyl)-4H-benzo[d] [1,3] oxazin-4-one and different amino acids namely[1 $]_{a-i}$, glycine, alanine, valine , leucine, isoleucine, serine, threonine, tyrosine and Phenyl alanine in (15 $\mathrm{ml}$.) of glacial acetic acid, then mixture was refluxed for $(5 \mathrm{~h})$. The mechanism ${ }^{28}$. involves nucleophilic addition reaction, as follows scheme (3.1).

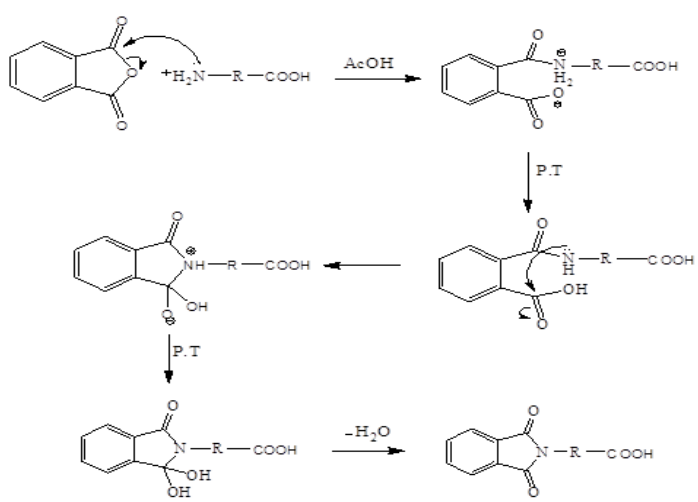

Fig. 1. The mechanism of preparing compound (3-7) 
The structure of compounds [3-7 $]_{a-i}$ was confirmed from its correct analytical and spectral data, FT-IR spectra of compounds $[5]_{a, 1}$, Fig. [(3.3),(3.4)], showed ${ }^{22}$ bands at (3300-2400) $\mathrm{cm}^{-1}$ for $(\mathrm{OH})$ of carboxylic acids, $(1780,1735) \mathrm{cm}^{-1}$ due to two $(\mathrm{N}-\mathrm{C}=\mathrm{O}),(1699) \mathrm{cm}^{-1}$ for $(\mathrm{C}=\mathrm{O})$ of carboxylic acid. While ${ }^{1} \mathrm{H}-\mathrm{NMR}$ spectrum of compound [5] $]_{a}$, Fig. (3.5), showed characteristic chemical shifts (DMSO- $d_{6}$ ) ppm as follow: the aromatic ring protons appeared as multiple at $\delta(7.69-8.32) \mathrm{ppm}$ and appearance singlet at $\delta(4.31)$ ppm due to $\mathrm{CH}_{2}$ proton and singlet in the region of $\delta 10.50$ due to $\mathrm{COOH}$ proton.

The ${ }^{1} \mathrm{H}-\mathrm{NMR}$ spectrum of compound [5] , Fig. (3.6) , display characteristic chemical shifts (DMSO- $\mathrm{d}_{6}$ ) ppm as follow: the aromatic ring protons appeared as multiple at $\delta(7.14-7.97) \mathrm{ppm}$ and appearance doublet signal at $\delta$ (3.14) ppm related to $\mathrm{CH}_{2}$ proton and triplate signal at $\delta$ (3.99) due to $\mathrm{CH}$ proton.

The FT-IR spectrum of compounds[ $[7]_{c}$, Fig. (3.7) showed disappearance of due to the carbonyl group of cyclic ester at (1766) $\mathrm{cm}^{-1}$ and appearance band at (1685) $\mathrm{cm}^{-1}$ due to carbonyl group of carboxylic acid. Also, absorption bands at (1643) $\mathrm{cm}^{-1},(1608) \mathrm{cm}^{-1}$ and (1587) $\mathrm{cm}^{-1}$ due to $(C=O)$ of amide, $\quad(C=N)$ and $(C=C)$ respectively . The ${ }^{1} \mathrm{H}-\mathrm{NMR}$ spectrum of compound [7] $]_{\mathrm{c}}$, Fig. (3.8), showed characteristic chemical shifts (DMSO- $d_{6}$ ) ppm as follow: a singlet signal at $\delta(12.36) \mathrm{ppm}$ for proton $\mathrm{COOH}$ group, Many signals in the region $\delta(7.19-8.73) \mathrm{ppm}$ that could be attributed to aromatic protons. Also appearance doublet signal at $\delta(4.13) \mathrm{ppm}$ for proton $\mathrm{CH}-\mathrm{N}$ group and many signals in the region $\delta(1.88) \mathrm{ppm}$ that could be attributed to proton of $\mathrm{CH}$ in $\mathrm{CH}\left(\mathrm{CH}_{3}\right)_{2}$ and doublet signal at $\delta(0.96)$ ppm is due to $\left(\mathrm{CH}_{3}\right)_{2}$ group. Where as ${ }^{13} \mathrm{C}-\mathrm{NMR}$ spectrum of compound [7], Fig. (3.9), showed: a signal at $\delta$ (172.91) ppm could be attributed to $\mathrm{COOH}$ group, while signal at $\delta$ (171.72) ppm is due to carbon of $\mathrm{C}=\mathrm{O}$ amide group. Signal at $\delta(164.45)$ due to carbon of ph- $\mathrm{C}=\mathrm{N}$ group. Many signal a $\delta(120-$ 140) ppm could be attributed to carbon of benzene ring. Also signal at $\delta$ (59.1) ppm related to $\mathrm{N}-\mathrm{CH}$ group. Signal appeared at $\delta$ (58.2) ppm is related to carbon of $\mathrm{CH}$ in $\mathrm{CH}\left(\mathrm{CH}_{3}\right)_{2}$. Two signal at $\delta(19.05-29.55) p p m$ could be attributed to $\left(\mathrm{CH}_{3}\right)_{2}$.
$\mathrm{N}$-phthaloyl amino acid chloride derivatives [8-12] $]_{\text {a-i }}$ through $\mathrm{h}$ the reaction of $\mathrm{N}$ - phthaloyl amino acids $[3-7]_{a-i}$ with thionyl chloride in dry benzene was refluxed for $(7 \mathrm{~h})$. A mechanism ${ }^{29}$ for this reaction may be outlined as followed in scheme (3.2) .

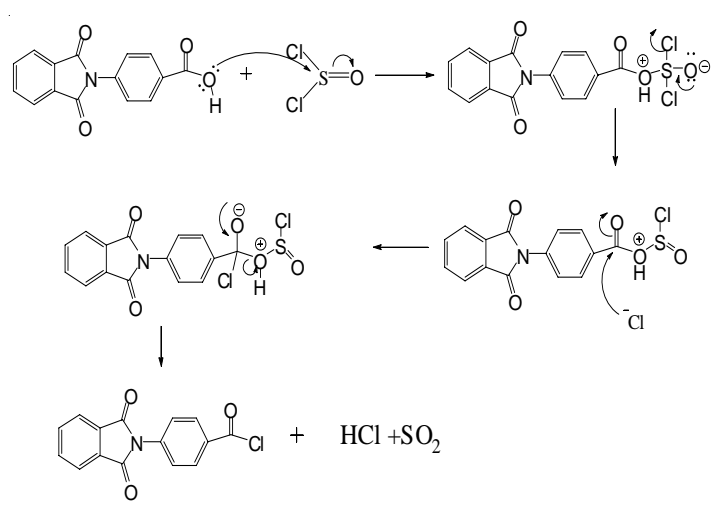

Fig. 2. The mechanism of preparing compound (8-12)

Compound $[10]_{b}$ was characterized by melting point and FT-IR spectrum . FT-IR spectrum of compound $[10]_{b}$, Fig. (3.10), showed ${ }^{23}$ the absence of absorption band at (1695) $\mathrm{cm}^{-1}$ and (3392) $\mathrm{cm}^{-1}$ due to (carbonyl, hydroxyl) group of carboxylic acid and presence of band at (1761) $\mathrm{cm}^{-1}$ related to acyl chloride .

Chemical modification of Poly(vinyl alcohol)[13-17 $]_{\text {a-i }}$ was obtained by reaction of PVA with compounds $[8-12]_{\mathrm{a}-\mathrm{i}}$ using the dimethyl formamide.

The compounds [13-17 $]_{a-i}$ were identified by FT-IR spectrum. FT-IR spectrum of compound $[15]_{a}$, Fig. (3.11) illustrated the presence of a large peak at $3390 \mathrm{~cm}^{-1}$ this peak is related to the stretching of $\mathrm{O}-\mathrm{H}$ from the intramolecular and intermolecular hydrogen bonds, which seen at $2908 \mathrm{~cm}^{-1}$ and $2943 \mathrm{~cm}^{-1}$ respectively due to the symmetric and asymmetric stretching vibrational of $\mathrm{C}-\mathrm{H}$ from alkyl groups ${ }^{30}$, showed the disappearance of absorption band at (1761) $\mathrm{cm}^{-1}$ due to acyl chloride and appearance of absorption band at (1724) $\mathrm{cm}^{-1}$ due to carbonyl group of ester ${ }^{31}$ and appearance of absorption bands at $(\mathrm{C}=\mathrm{O})$ of cyclic imide at $(1710-1778) \mathrm{cm}^{-1}$. 
The ${ }^{1} \mathrm{H}-\mathrm{NMR}$ spectrum of compound [13], Fig. (3.12), showed ${ }^{32,33}$ the following characteristic chemical shifts (DMSO- $d_{6}$ ) ppm showed the following signals: signal at $\delta(6.63) \mathrm{ppm}$ for proton $(\mathrm{CH}=\mathrm{CH})$ group, singlet peak at $\delta(4.48) \mathrm{ppm}$ for proton of $\left(\mathrm{N}-\mathrm{CH}_{2}\right)$ group, triplet peak at $\delta(4.24) \mathrm{ppm}$ for $(\mathrm{CH})$ group and doublet peak at $\delta(1.37) \mathrm{ppm}$ for proton $\left(\mathrm{CH}_{2}\right)$ group.

The ${ }^{1} \mathrm{H}-\mathrm{NMR}$ spectrum of compound [15], Fig. (3.13), showed ${ }^{32,33}$ the following characteristic chemical shifts (DMSO- $d_{6}$ ) ppm showed the following signals: many signals at $\delta(8.30-8.32)$ $\mathrm{ppm}$ for proton aromatic protons.triplet peak at $\delta(4.32-4.77) \mathrm{ppm}$ for proton of $(\mathrm{N}-\mathrm{CH})$ group, doublet peak at $\delta$ (3.99) ppm for protonC $\mathrm{H}_{2}$ in $\left(\mathrm{CH}_{2}-\mathrm{OH}\right)$, singelt peak at $\delta(3.45)$ ppm for proton $(\mathrm{OH})$ group, triplet peak at $\delta(3.05) \mathrm{ppm}$ for $\left(\mathrm{CH}-\mathrm{CH}_{2}\right)$ group and doublet peak at $\delta(1.54)$ ppm for proton $\left(\mathrm{CH}_{2}-\mathrm{CH}\right)$ group .
The UV-Vis spectrum of compound [14], Fig. (3.14) shows the absorption peaks at (332-402) may attributed to $\left(\pi-\pi^{\star}\right)$ and $\left(n-\pi^{*}\right)$.

\section{Biological Activity \\ Antibacterial activity}

All the newly synthesized derivatives were screened for their in vitro antimicrobial activity against Escherichia coli, Bacillus cereus by measuring the zone of inhibition in $\mathrm{mm}$. Result showed that compounds[6] and [16] $]_{f}$ exhibit some antibacterial activity with penciline against $E$.coli while compounds $[15]_{f}$ and $[17]_{f}$ showed antibacterial activity closed to penciline against Bacillus cereus. Resalts of all compounds all compounds and their antibacterial activities listed in Table. (3.4).

Table. 1: FT-IR data of compounds[3-5 $]_{\mathrm{a}-\mathrm{i}}$

\begin{tabular}{|c|c|c|c|c|c|c|}
\hline Com. No. & $(\mathrm{O}-\mathrm{H}) \mathrm{cm}^{-1}$ & $(\mathrm{C}-\mathrm{H})$ & ) arom. $\mathrm{cm}^{-1}(\mathrm{C}-\mathrm{H}$ & H) aliph. $\mathrm{cm}^{-1}$ & $(\mathrm{C}=\mathrm{O})$ imide. $\mathrm{cm}^{-1}$ & $(\mathrm{C}=\mathrm{O})$ carboxlic \\
\hline$[3]_{a}$ & $3400-2400$ & & 3053 & 2968-2879 & $1732-1770$ & 1681 \\
\hline$[3]_{b}$ & 3473 & & 3072 & 2987-2873 & $1722-1784$ & 1691 \\
\hline$[3]_{c}$ & 3392 & & 3066 & $2970-2890$ & $1743-1782$ & 1680 \\
\hline$[3]_{d}$ & $3400-2400$ & & 3055 & 2965-2877 & $1728-1770$ & 1690 \\
\hline$[3]_{e}$ & 3464 & & 3075 & $2939-2855$ & $1716-1774$ & 1691 \\
\hline$[3]_{f}$ & 3462 & & 3084 & 2939-2872 & $1749-1772$ & 1697 \\
\hline$[3]_{g}$ & 3442 & & 3093 & $2920-2850$ & $1745-1774$ & 1693 \\
\hline$[3]_{h}$ & $3400-2600$ & & 3051 & 2985-2939 & $1718-1735$ & 1685 \\
\hline$[3]_{i}$ & $3400-2400$ & & 3086 & 2972-2926 & $1722-1780$ & 1680 \\
\hline$[4]_{a}$ & 3344 & & 3049 & 2989-2883 & $1734-1780$ & 1683 \\
\hline$[4]_{b}$ & $3400-2400$ & & 3080 & 2990-2951 & $1755-1786$ & 1697 \\
\hline$[4]_{c}$ & $3300-2400$ & & 3049 & 2966-2890 & $1712-1761$ & 1691 \\
\hline$[4]_{d}$ & $3400-2600$ & & 3109 & $3018-2990$ & $1712-1764$ & 1701 \\
\hline$[4]_{e}$ & 3396 & & 3090 & 2933-2877 & $1710-1772$ & 1696 \\
\hline$[4]_{f}$ & 3394 & & 3089 & 2947-2885 & $1735-1776$ & 1697 \\
\hline$[4]_{g}$ & 3462 & & 3084 & 2939-2872 & $1749-1772$ & 1697 \\
\hline$[4]_{h}$ & 3435 & & 3088 & 2962-2893 & $1716-1772$ & 1685 \\
\hline$[4]_{\mathrm{i}}$ & 3392 & & 3045 & 2980-2943 & $1710-1770$ & 1662 \\
\hline$[5]_{b}$ & 3392 & & 3089 & 2995-2941 & $1724-1784$ & 1695 \\
\hline$[5]_{c}$ & 3408 & & 3041 & $2970-2881$ & $1726-1784$ & 1690 \\
\hline$[5]_{d}$ & $3400-2400$ & & 3115 & $2960-2860$ & $1732-1782$ & 1683 \\
\hline$[5]_{e}$ & $3400-2400$ & & 3064 & $2926-2854$ & $1716-1780$ & 1683 \\
\hline$[5]_{f}$ & 3398 & & 3024 & 2990-2889 & $1732-1776$ & 1681 \\
\hline$[5]_{g}$ & 3408 & & 3097 & 3039-2926 & $1716-1780$ & 1690 \\
\hline$[5]_{h}$ & $3400-2600$ & & 3026 & $2929-2856$ & $1716-1734$ & 1701 \\
\hline
\end{tabular}


Table. 2: FT-IR data of compounds[6,7 $]_{\mathrm{a}-\mathrm{i}}$

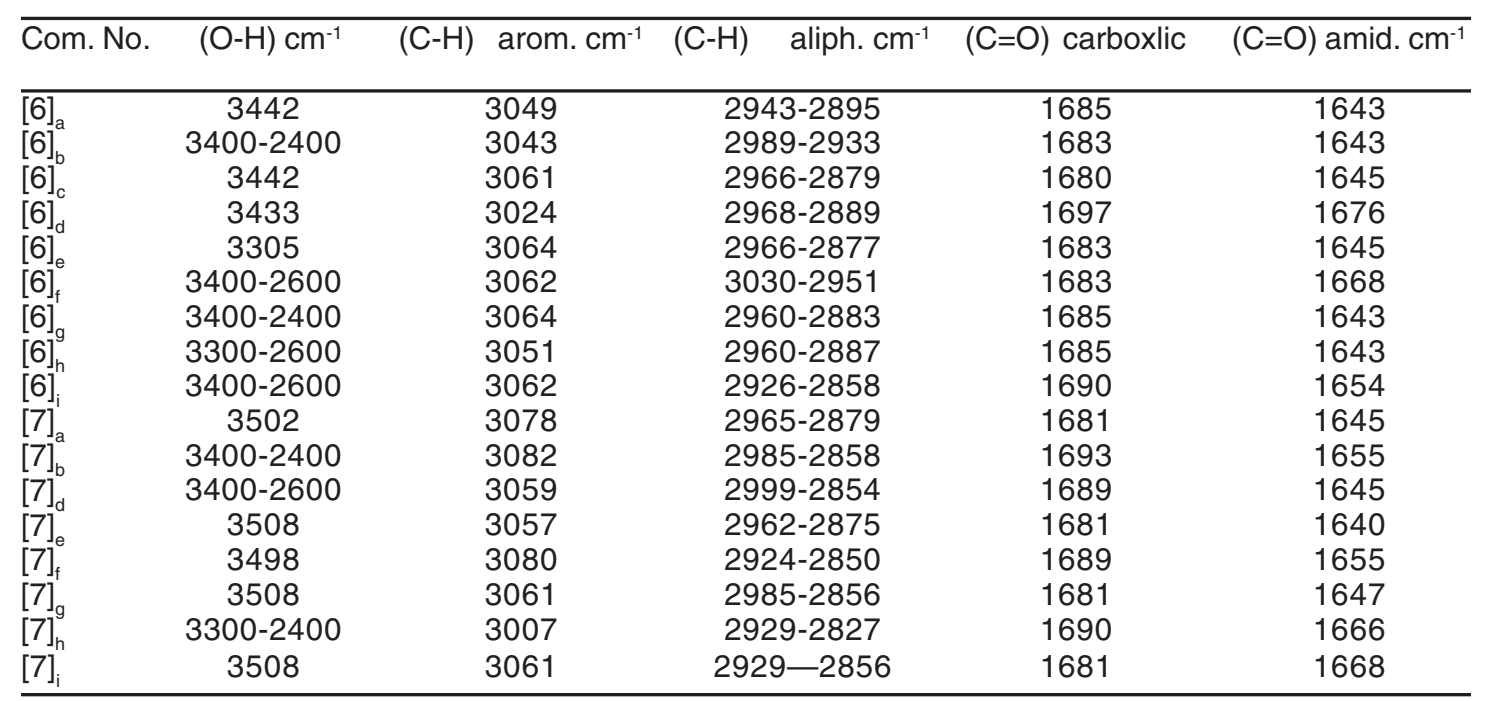

Table. 3 : The inhibition zone of some synthesized compounds

\begin{tabular}{lcc}
\hline Compound & $\begin{array}{c}\text { E.coli } \\
(\mathrm{mm})\end{array}$ & $\begin{array}{c}\text { Bacillus cereus } \\
\mathrm{mm}\end{array}$ \\
\hline Peinciline & 16 & 22 \\
DMSO & Nil & Nil \\
{$[3]_{\mathrm{h}}$} & 10 & 10 \\
{$[13]_{\mathrm{h}}$} & 15 & 16 \\
{$[4]_{\mathrm{h}}$} & 10 & 10 \\
{$[14]_{\mathrm{h}}$} & 10 & 21 \\
{$[5]_{\mathrm{f}}$} & 15 & 16 \\
{$[15]_{\mathrm{f}}$} & 15 & 23 \\
{$[6]_{\mathrm{f}}$} & 16 & 13 \\
{$[16]_{\mathrm{f}}$} & 16 & 21 \\
{$[7]_{\mathrm{f}}$} & 14 & 18 \\
{$[17]_{\mathrm{f}}$} & 14 & 25 \\
\hline
\end{tabular}

Table. 4 : The inhibition zone of some synthesized compounds

\begin{tabular}{lcc}
\hline Compound & $\begin{array}{c}\text { E.coli } \\
\mathrm{mm}\end{array}$ & $\begin{array}{c}\text { Bacillus cereus } \\
\mathrm{mm}\end{array}$ \\
\hline Penciline & 16 & 22 \\
DMSO & $\mathrm{Nil}$ & $\mathrm{Nil}$ \\
{$[3]_{\mathrm{h}}$} & 10 & 10 \\
{$[13]_{\mathrm{h}}$} & 15 & 16 \\
{$[4]_{\mathrm{h}}$} & 10 & 10 \\
{$[14]_{\mathrm{h}}$} & 10 & 21 \\
{$[5]_{\mathrm{f}}$} & 15 & 16 \\
{$[15]_{\mathrm{f}}$} & 15 & 23 \\
{$[6]_{\mathrm{f}}$} & 16 & 13 \\
{$[16]_{\mathrm{f}}$} & 16 & 21 \\
{$[7]_{\mathrm{f}}$} & 14 & 18 \\
{$[17]_{\mathrm{f}}$} & 14 & 25 \\
\hline
\end{tabular}
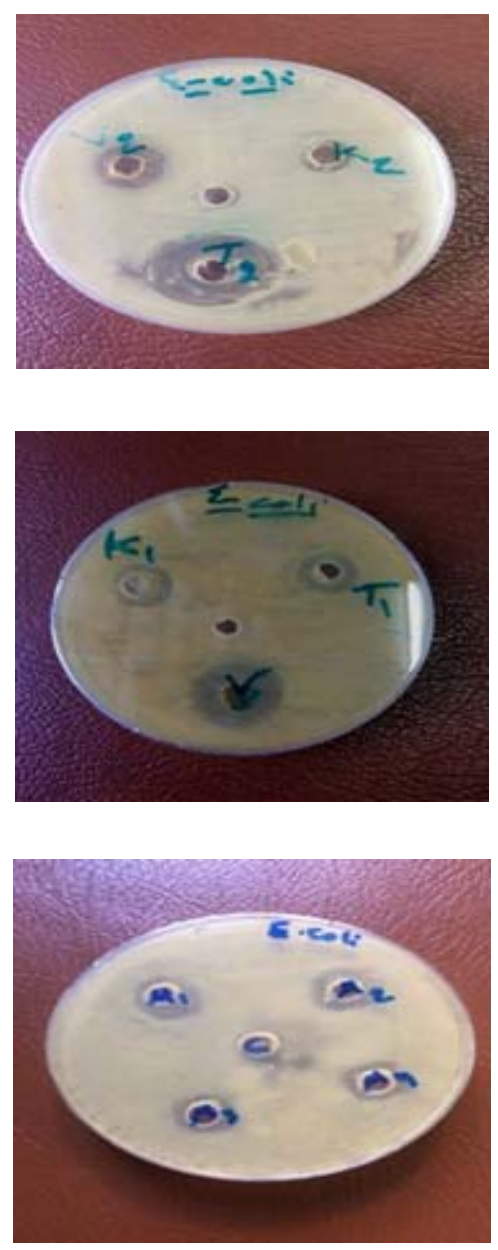

Fig. 3. Antibacterial activities of compounds against E.coli 

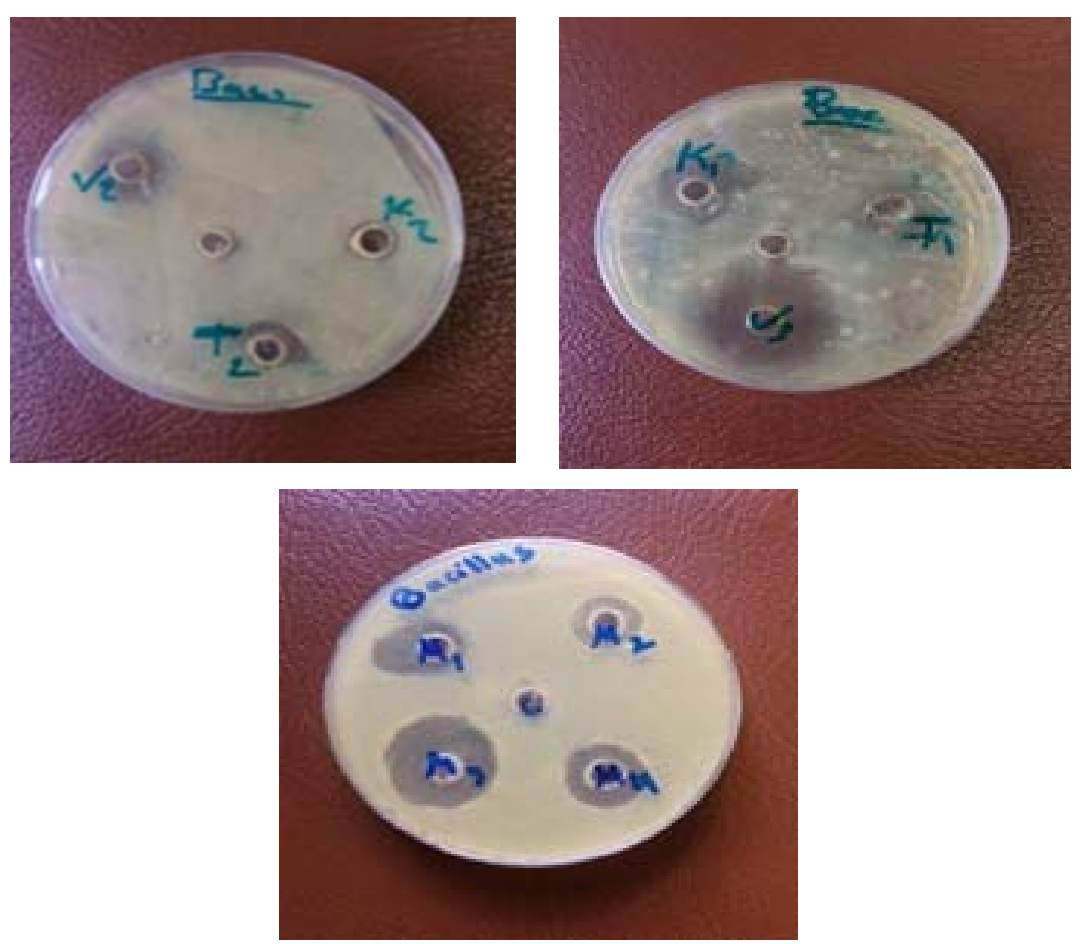

Fig. 4. Antibacterial activities of compounds against Bacillus cereus

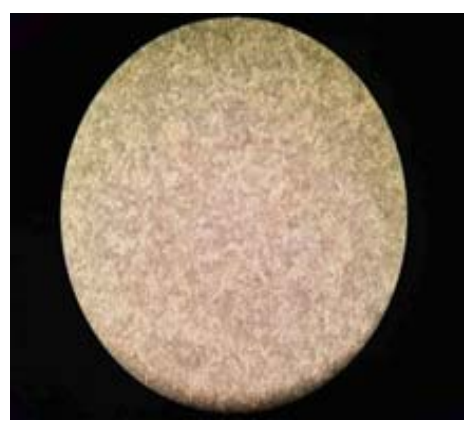

Fig. 5. Image of before well Staining

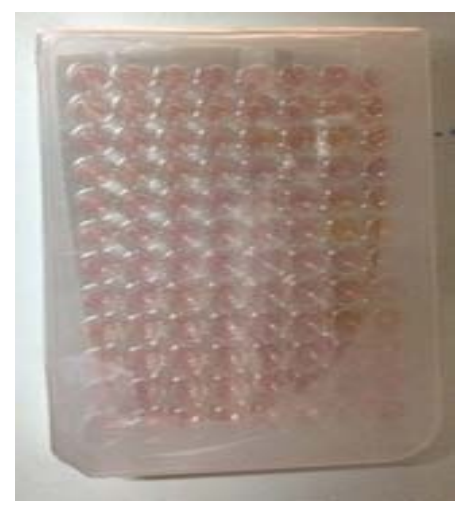

Fig. 7. Image of plate before Staining

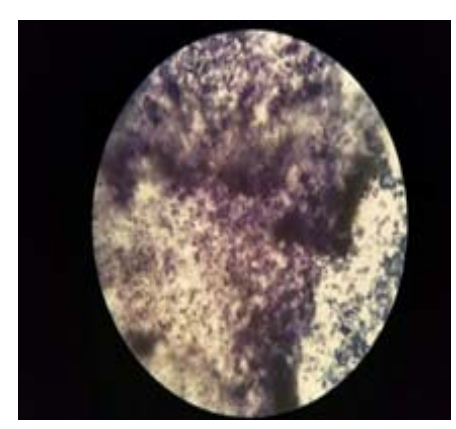

Fig. 6. Image of well after Staining

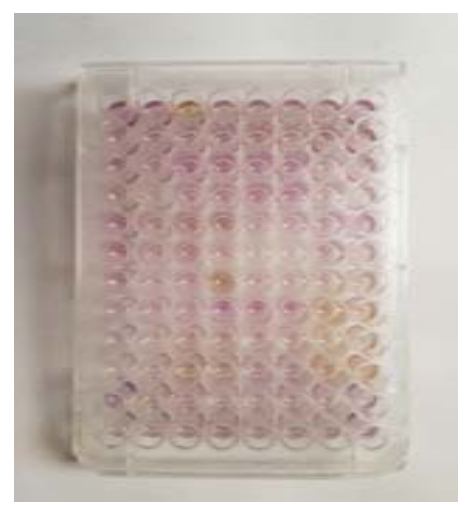

Fig.8. Image of plate after Staining 


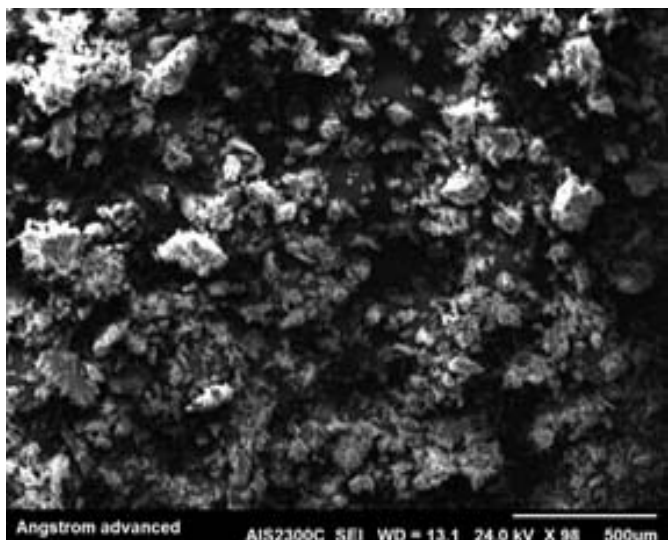

Fig. 9. SEM of compound[9]f

\section{Anticancer activity}

Fifteen compounds modified polyvinyl alcohol were selected for examend their anticancer activity in Bio-technology research center, Al-Nahrain University, Baghdad, Iraq. Two cell lines were used (mice intestines carcinoma cell line L20b and human pelvic rhabdomyosarcoma (RD). according to the method described by Freshney ${ }^{26}$ Results are expressed in percentage. All compounds except [17] $]_{b}$ and $[17]_{d}$ showed more than $50 \%$ inhibition for mice intestines carcinoma cell line, while these compounds $[17]_{b}$ and $[17]_{d}$ exhibit inhibition more than $50 \%$ inhibition for human pelvic rhabdomyosarcoma.

\section{CONCLUSION}

Compounds react with $\mathrm{SOCl}_{2}$ in the presence of benzene to produce compounds.

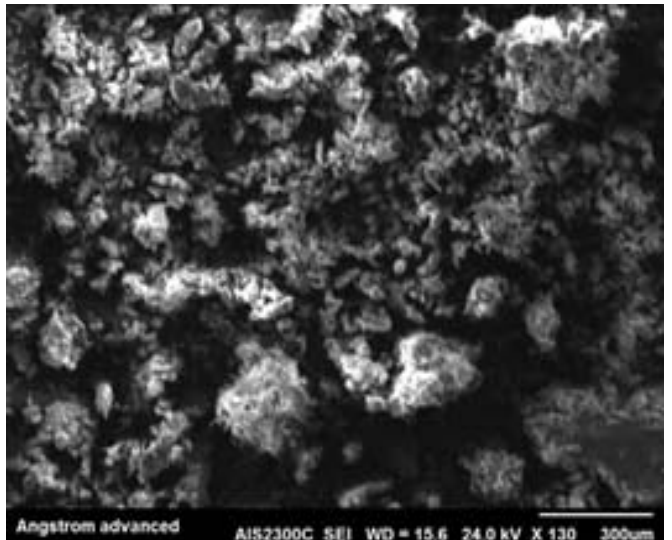

Fig. 10. SEM of compound[9]f

Chemical modification of Poly(vinyl alcohol) were obtained by reaction of PVA with compounds using the dimethyl formamide to give compounds. The structure of the synthesized compounds was characterized by their analytical and spectral data as, IR spectra, ${ }^{1} \mathrm{H},{ }^{13} \mathrm{C}-\mathrm{NMR}$, Elemental analysis (CHN), UV-Vis Spectroscopy, Scanning electron microscopy (SEM), Antibacterial activity were screened via two kinds of bacteria. Also, anticancer activity were examined for most of the modified polyvinyl alcohol.

\section{ACKNOWLEDGMENTS}

I would like to thank the University of Baghdad- Faculty of Education (Ibn-Al-Haitham) Department of Chemistry to help me for complete this article.

\section{REFRENCES}

1. SS. Rajput and R.A. Mohammed Ali Sayyed. Synthesis, characterization and Biological Evaluation of 3,4-bis(substituted-Phenyl)-7(2,6- dichloro-4-(trifluoromethyl)phenyl)-7Hpyrrolo [2,3-C: 5,4- C'] diisoxazoles from2, 6dichloro-4-trifluoro methyl aniline. Shankarsing Sardarsing Rajput, IJCTPR., 2017, 2321-3760, 5(1): 17-22 .

2. A. H. Samir, I. y. Majeed and S. M. Hasan, IbnAl-haitham J. for Pure \& Appl. Sci., 2014, 27(3), 407-420 .

3. SS. Rajput and RM.Sayyed. Synthesis and formylation of cyclic imides using VilsmeireHaack reaction from 2, 6 dichloro-4triflouromethyl aniline and their anti-microbial activity. World Journal of Pharmaceutical Research., 2015, 12, 1689-1695.

4. MM .Patil and SS. Rajput.Succinimides synthesis and biological activity. International Journal of Pharmacy and Pharmaceutical Sciences., 2014, 11, 0975-1491.

5. RS.Dhivare and SS. Rajput. Synthesis and antimicrobial evauation of some novel bisheterocyclicchalcones from cyclic imides under microwave irradiation. Chemical Science Review and letter., 2015, 4(15), 937-944.

6. FC Pennington, PA Guercio and IA. Solomons. The antihypertensive effect of a selective 
central muscarinic cholinergic antagonist: $\mathrm{N}$-(4- diethyl amino -2-butynyl)-succinimide. J. Am Chem Soc, 1953, 75(9), 2261-1.

7. DL Musso, FR Cochran, JL Kelley, EW McLean, JL Selph and GC Rigdon, Design and synthesis of (E)-2-(4,6-Difluoro-1indanylidene) acetamide, a potent, centrally acting muscle relaxant with anti- inflammatory and analgesicactivity. J Med Chem., 2003, 46(3), 399-408.

8. JH Mansoory and SS Rajput. Synthesis, characterization and biological evaluation of some novel Schiff's bases from Halovinyl aldehyde and 4- amino-5(pyridine-4-yl)-4H1, 2, 4-triazole-3-thiol. Der Pharma Chemica., 2015, 7(10), 510-514.

9. M.lsaka, W.Prathumpai, P.Wongsa, M. Tanticharoen and Hirsutellone F.A dimer of antitubercular alkaloids from the seed fungus Trichoderma species BCC7579. Org Lett., 2006, 8(13):2815-7.

10. A. M.Al-Azzawi and A. S.Hamd, synthesis, characterization and antimicrobial activity evaluation of new cyclic imides containing 1,3,4-thiadiazole and 1,3,4- oxadiazole moieties. International journal of research in pharmacy and chemistry., 2013, 3(4), 2231-2781.

11. GS Gruzdyes,VA Zincchenko, RI Slovtsov. The Chemical Protection of Plants, by Gruzdyes GS.Mir Publishers, Moscow., 1983, 272.

12. YL Nene, PN Thapliyal. Fungicides In Plant Disease Control, 3th Ed., Oxford \& IBH Publishing Co. Pvt. Ltd., New Delhi. 1993, 170.

13. US RamuluSree.Chemistry of Insecticides \& Fungicides, 2nd Ed., Oxford \& IBH Publishing Co. Pvt. Ltd., New Delhi. 1995, 246.

14. Ullmanns. Encyclopedia of Industrial Chemistry, 5th Ed., Vol. A 20, Editors Elvers B, Hawkins S, Sehulz G. 1991,190.

15. OMO Habib,EB Moawad, SD Badawy, JAF Mansour. Some New Heterocyclic Sulphonates with potential antimicrobial activity: J. Prakt. Chem. 1990; 332: 791. Skehan, P.; Storeng R, Scudiero. D. J. Natl, Cancer Ins., 1990, 82, 1107.

16. O.W. Guirguis, and M.T.H. Moselhey. Thermal and structural studies of poly(vinyl alcohol) and hydroxypropyl cellulose blends Natural Science., 2012, 4(1), 57-67.

17. A.M.Shehap and Dana S.Akil.Structural and optical properties of $\mathrm{TiO} 2$ nanoparticles/PVA for different composites thin films. Int. J. Nanoelectronics and Materials., 2016, 9, 17-36

18. SN Zadeh, S Rajabnezhad, Zandkarimi M, $S$ Dahmardeh, Mir L, Mucoadhesive
Microspheres of Chitosan and Polyvinyl Alcohol as A Carrier for Intranasal Delivery of Insulin: In Vitro and In Vivo Studies. MOJ Bioequiv Availab., 2017, 3(2), 00030. DOI: 10.15406/mojbb. 2017.03.00030

19. A.Samzadeh-Kermani,M.Mirzaeeand Mansour Ghaffari-Moghaddam. Polyvinyl Alcohol/ Polyaniline/ ZnO Nanocomposite: Synthesis, Property. Advances in Biological Characterization and Bactericidal Chemistry., 2016, 6, 1-11

20. T. Sumer Gaaz, Abu Bakar Sulong, Majid Niaz Akhtar, Abdul Amir H. Kadhum, Abu Bakar Mohamad and Ahmed A. Al-Amiery Properties andApplications of Polyvinyl Alcohol, Halloysite Nanotubes and Their Nanocomposites. Molecules., 2015, 20, 22833-22847.

21. G.Deepa, P. Pantel, M.shah; P.S.Patel; Der pharmachemia., 2012, 4(2), 626-628.

22. YA .Nagiev, J.Russiam. Organic chemistry., 2012, 48(3), 469-472.

23. M.S Fouad, I .RedhaAl-Bagati ;A. Al -Juboori; Al-Mustansiriya., J. Sci , 2006, 17(3), 15-26.

24. L.S.Ahamed. Synthesis of New PolyesterAmides from Polyvinyl Alcohol and Convert Some of Them to Polyester-Imide, Journal of Al-Nahrain University., 2011, 14(2), 29-42.

25. A.L Barry, The Antimiccrobial Susceptibility Test: principle and practices, (Len and Febiger, Philadelphia, USA), BiolAbstr., 1977, 180(64), 25183.

26. RI. Freshney, "Culture of Animal Cells: A manual of Basic Technique and Specialized Applications," $6^{\text {th }}$ Edition, Wiley: New York, 2010.

27. S. Gao .et al,"Antiproliferative effect of octreotide on gastric cancer cells mediated by inhibition of Akt/PKB and telomerase," World J. Gastroenterol., 2003, 9(10), 2362-2365.

28. E.T. Ali ;K.M.Lazim AL-Aliawy and J.H. Tomma. IBN AL-Hatham J. For pure and Appl .Sci . 2011, 24(3).

29. Solomons and fryhle "organic chemistry main and advanced" maestro Awiley Brand., 2013.

30. H. Awada and C. Daneault, Chemical Modification of Poly(Vinyl Alcohol) in Water Appl. Sci. 2015, 5, 840-850 .

31. E. G. Crispim, J. F. Piai1, A. R. Fajardo, E. R. F. Ramos, T. U. Nakamura, C. V. Nakamura, A. F. Rubira, E. C. Muniz, eXPRESS Polymer Letters., 2012, 6(5), 383-395. 2012, 2(5), 79-84

32. Smith J.G.,OrganicChemistry, 1st ed, MC Graw Hill, New York , 2006, 522.

33. Roman Jantas, Zbigniew Draczynski, Lucyna Herczynska, Dawid Stawski, Poly(vinyl alcohol)-Salicylic Acid Conjugate: Synthesis and Characterization, American Journal of Polymer Science., 2012, 2(5), 79-84 DOI: 10.5923/j.ajps.20120205.01. 